\title{
A COMPARATIVE STUDY BETWEEN EPIDURAL BUPRENORPHINE AND EPIDURAL TRAMADOL FOR POSTOPERATIVE ANALGESIA IN PATIENTS UNDERGOING LOWER ABDOMINAL SURGERIES
}

\author{
Debashish Mondal11, Deba Gopal Pathak2, Ismatara Begum³, Binod Pegu4, Ram Chandraji Chauhan 5 \\ ${ }_{1}^{1}$ Postgraduate Student, Department of Anaesthesiology and Critical Care, Silchar Medical College and Hospital, Silchar. \\ 2Professor and HOD, Department of Anaesthesiology and Critical Care, Silchar Medical College and Hospital, Silchar. \\ ${ }^{3}$ Associate Professor, Department of Anaesthesiology and Critical Care, Silchar Medical College and Hospital, Silchar. \\ ${ }_{4}^{4}$ Postgraduate Student, Department of Anaesthesiology and Critical Care, Silchar Medical College and Hospital, Silchar. \\ 5 Postgraduate Student, Department of Anaesthesiology and Critical Care, Silchar Medical College and Hospital, Silchar.
}

\section{ABSTRACT}

\section{BACKGROUND}

In the present study, we compared the analgesic effect between buprenorphine hydrochloride and tramadol hydrochloride administered through epidural route for the purpose of postoperative analgesia in patients undergoing lower abdominal surgical procedures.

The aim of this study is to evaluate and compare the efficacy between epidurally administered buprenorphine and tramadol in providing post-operative analgesia, along with their onset and duration of analgesia, side effects.

\section{MATERIALS AND METHODS}

Our study included 100 patients belonging to ASA I and ASA II who came for elective lower abdominal surgeries, (Gynaecological and general surgical procedures), who were randomly divided into two groups comprising of 50 each. Two groups designated as Group A receiving Inj. Tramadol hydrochloride $50 \mathrm{mg}$ and Group B receiving Inj. Buprenorphine hydrochloride 100 micrograms via epidural route (epidural catheterisation done). Patients in both groups were followed up till 24 hours post-surgery. VAS (Visual Analogue Score) score for pain intensity, onset and duration of analgesia, vital signs and side effects were monitored at $0,15,30$ minutes and 1, 2, 3, 6, 8, 10, 12, 24 hours respectively in the postoperative period.

\section{RESULTS}

The onset of analgesia was faster in Group A; however, the duration of analgesia was shorter as compared to Group B. The mean onset of analgesia in Group A was found to be $9.85 \pm 3.75$ minutes while in Group B, it was found to be $15.71 \pm 5.85$ minutes. The mean duration of postoperative analgesia was found to be $359.02 \pm 83.85$ (SD) minutes in Group A while in Group B it was $547.52 \pm$ 94.22 ( SD) minutes, $p$ value $<0.0001$ which is considered extremely significant. The pain score (VAS score), was also better (Less than 3) in Group B. During the entire study period, all the patients remained haemodynamically stable and major adverse effect like respiratory depression was not observed. However, the incidence of nausea, vomiting, pruritus, hypotension was observed in Group B more as compared to Group A.

\section{CONCLUSION}

At the end of the study, we came to the conclusion that epidural buprenorphine provides comparatively longer and better quality of analgesia as compared to epidural tramadol. The appreciable side effects found with injection buprenorphine were nausea, vomiting, pruritus which could be subsided by administration of antiemetics and antihistaminics respectively.

\section{KEYWORDS}

Buprenorphine, Tramadol, Visual Analogue Score (VAS) of Pain, Epidural, Postoperative Analgesia.

HOW TO CITE THIS ARTICLE: Mondal D, Pathak DG, Begum I, et al. A comparative study between epidural buprenorphine and epidural tramadol for postoperative analgesia in patients undergoing lower abdominal surgeries. J. Evolution Med. Dent. Sci. 2017;6(31):2552-2556, DOI: 10.14260/Jemds/2017/552

\section{BACKGROUND}

Tramadol, a centrally acting analgesic, is a synthetic analogue of codeine that has moderate affinity for mu receptors and a weak kappa and delta opioid receptor affinity which is 5 to 10 times less potent than morphine as an analgesic. In addition to mu opioid agonist effect tramadol enhances the function of the

Financial or Other, Competing Interest: None.

Submission 02-03-2017, Peer Review 03-04-2017,

Acceptance 08-04-2017, Published 17-04-2017.

Corresponding Author:

Dr. Debashish Mondal,

Old PG Boys Hostel,

Room No. 8, Silchar Medical College

and Hospital, Silchar.

E-mail:dmondal2005@gmail.com

DOI: $10.14260 /$ jemds $/ 2017 / 552$

spinal descending inhibitory pathways by inhibition of neuronal reuptake of norepinephrine and 5hydroxytryptamine (Serotonin) as well as presynaptic stimulation of 5-hydroxytryptamine release. In volunteers, naloxone has been found to antagonise only an estimated $30 \%$ effect of tramadol. 1

Buprenorphine hydrochloride is a semisynthetic highly lipophilic opioid derived from thebaine, an opium alkaloid related to morphine. It is a long-acting analgesic with narcotic agonist and antagonist actions. It is estimated that affinity of buprenorphine for mu receptors is 50 times greater than that of morphine and subsequent slow dissociation from these receptors accounts for its prolonged duration of action and resistance to antagonism by naloxone. ${ }^{2}$

The purpose of our study was to compare the efficacy of epidurally administered buprenorphine with that of tramadol 
for postoperative pain relief in patients undergoing lower abdominal surgeries, also to compare the onset and duration of analgesia and side effects of the two drugs.

\section{MATERIALS AND METHODS}

The study was conducted after approval of ethical committee of the institution (Silchar Medical College and Hospital), Silchar. A written and informed consent was obtained from all patients. Study size comprised of 100 patients who came for elective lower abdominal surgeries and was randomly allocated into two groups of 50 each.

Group A- Receiving Inj. Tramadol hydrochloride $50 \mathrm{mg}$. $(\mathrm{N}=50)$.

Group B- Receiving Inj. Buprenorphine hydrochloride 100 microgram. ( $N=50)$.

\section{Patients Inclusion Criteria}

Patients posted for various elective lower abdominal surgeries.

- Age group 18 - 60 years of both sex.

- Patients in ASA I and II.

\section{Patients Exclusion Criteria}

- ASA grade III and IV.

- All contraindications for epidural anaesthesia.

- Uncooperative patients/patient refusal.

- Severe haemorrhage or shock.

- Coagulation defects or on anticoagulant therapy.

- Local inflammation.

- History of opioid abuse.

- Allergy to any of the drugs used in the study.

Equipment Used

1. IV cannula and IV fluids.

2. Epidural set - $18 \mathrm{G}$ Tuohy needle and catheter.

3. Syringes: $2 \mathrm{cc}, 5 \mathrm{cc}, 10 \mathrm{cc}$.

4. Boyle's apparatus.

5. Resuscitation equipment, oxygen, Ambu Bag, Laryngoscope, tracheal tubes of appropriate sizes, suction apparatus and emergency drug tray.

6. Monitoring equipment.

- Pulse oximeter.

- ECG.

- NIBP.

- VAPS.

Drugs Used: Study Agent.

- Injection Tramadol hydrochloride ampoule (Preservative free).

- Injection Buprenorphine hydrochloride ampoule (Preservative free).

\section{Others,}

- Inj. Ondansetron.

- Inj. Ranitidine.

- Inj. Phenergan.

- Inj. Pentazocine.

\section{Procedure}

\section{Step 1}

IV lines secured and all patients were preloaded with $500 \mathrm{~mL}$ Ringer's lactate solution.

\section{Step 2}

Pre-operative vitals were recorded (NIBP, HR, SPO2, RR). Premedication done with Inj. Ondansetron $4 \mathrm{mg}$ IV, Inj. Ranitidine 40 mg IV.

\section{Step 3}

Under strict aseptic precaution, L3-L4 interspace was identified by palpation.

\section{Step 4}

After local infiltration, an epidural puncture was made by loss of resistance technique to air by 18 G Tuohy needle at L3-L4 interspace.

\section{Step 5}

Epidural catheter passed through needle, thereafter needle was withdrawn and catheter secured. Inj. 2\% Xylocaine with adrenaline given as test dose.

\section{Step 6}

Patient was then administered spinal anaesthesia one space below the epidural puncture site using injection Bupivacaine heavy $0.5 \%$ and operation carried out after assessment of adequate level of block.

\section{Step 7}

In postoperative ward, patients complaining of pain clinically correlating with VAS Score 3 and above were assessed and the study drug was given via the epidural catheter. In Group A Inj. Tramadol $50 \mathrm{mg}$ diluted in normal saline to $12 \mathrm{~mL}$ given via epidural route while in Group B Inj. buprenorphine 100 micrograms diluted in normal saline to $12 \mathrm{~mL}$ was administered.

VAS score for intensity of pain, onset and duration of analgesia, vital signs, side effects were monitored at $0,15,30$ minutes and 1, 2, 3, 6, 8, 10,12, 18, 24 hours respectively.

Analgesia is scored by VAS Score ranging from 0 to 10.

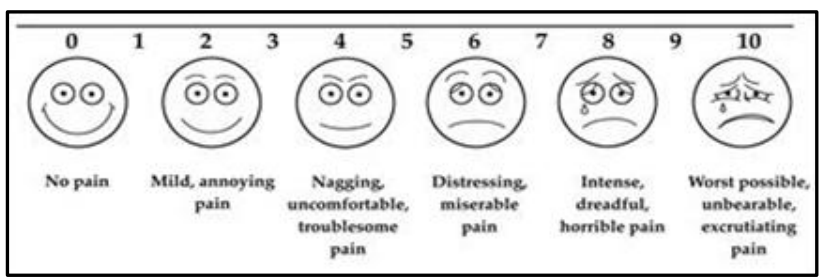

Figure 1. Visual Analogue Scale

\section{Step 8}

The duration of analgesia will be calculated from administration of $1^{\text {st }}$ dose of the drug till the requirement of second dose and then the study will be abandoned. Onset time of analgesia is the time from administration of drug to symptomatic relief.

\section{Statistical Analysis}

The data compiled were analysed with GraphPad instat software 3, statistical software. For qualitative data, Fisher's exact test was used. Quantitative data was analysed with student $t$ test.

$P$ value was determined. $p>0.05$-not significant, $p<0.05$ significant, $\mathrm{p}<0.001$ highly significant, $\mathrm{p}<0.0001$ extremely significant. 


\section{RESULTS}

The two groups were comparable in terms of demographic data, ASA grading, type of surgeries and duration of analgesia. The mean onset of analgesia in Group A was $9.85 \pm 3.71$ minutes while in Group B it was found to be $15.71 \pm 5.85$ minutes. The mean duration of analgesia between two groups, Group A was found to be $359.02 \pm 83.853$ (SD) minutes while in Group B it was found to be $547.52 \pm 94.22$ (SD) minutes, the tailored $p$ value being $<0.0001$ which is considered extremely significant. Samples are age, weight and sex matched, $\mathrm{p}$ value $>0.05$. The side effects between the two drugs were also comparable, in Group A the complications reported were nausea in 3 cases and vomiting in 9 cases while in group B nausea in 5 cases, vomiting 14 cases, itching 5 cases and hypotension with vomiting in 2 cases.

\begin{tabular}{|c|c|c|c|}
\hline $\begin{array}{c}\text { Demographic } \\
\text { Parameters } \\
\text { Mean } \pm \text { SD }\end{array}$ & $\begin{array}{c}\text { Group A } \\
\text { (N= 50) }\end{array}$ & $\begin{array}{c}\text { Group B } \\
\text { (N=50) }\end{array}$ & P value \\
\hline Age in years & $36.5 \pm 10.9$ & $34.12 \pm 9.05$ & 0.2396 \\
\hline Weight in kg & $53.86 \pm 8.68$ & $54.64 \pm 7.82$ & 0.6379 \\
\hline & $\begin{array}{c}\text { Male }=32 \\
(64 \%) \\
\text { Sex }\end{array}$ & $\begin{array}{c}\text { Male }=29 \\
(58 \%)\end{array}$ & 0.6820 \\
& $\begin{array}{c}\text { Fale }=18 \\
(36 \%)\end{array}$ & $\begin{array}{c}\text { Female }=21 \\
(42 \%)\end{array}$ & \\
\hline \multicolumn{3}{|c|}{ Samples are age, sex } \\
Inference & \multicolumn{3}{|c|}{ and weight matches with p $>0.05$} \\
\hline \multicolumn{2}{|c|}{ Table 1. Comparison of Demographic Parameter } \\
\hline
\end{tabular}

\begin{tabular}{|c|c|c|c|c|}
\hline $\begin{array}{c}\text { ASA Physical } \\
\text { Status }\end{array}$ & \multicolumn{2}{|c|}{$\begin{array}{c}\text { Group A } \\
(\mathbf{N}=\mathbf{5 0}\end{array}$} & \multicolumn{2}{c|}{$\begin{array}{c}\text { Group B } \\
(\mathbf{N}=\mathbf{5 0})\end{array}$} \\
\hline & $\begin{array}{c}\text { No. of } \\
\text { Patients }\end{array}$ & $\begin{array}{c}\text { Percent } \\
(\%)\end{array}$ & $\begin{array}{c}\text { No. of } \\
\text { Patients }\end{array}$ & $\begin{array}{c}\text { Percent } \\
(\%)\end{array}$ \\
\hline I & 43 & 86 & 45 & 90 \\
\hline II & 7 & 14 & 5 & 10 \\
\hline Table 2. Distribution of Patients in Groups According to \\
ASA Physical Status
\end{tabular}

P value 0.7596

\begin{tabular}{|c|c|c|c|c|}
\hline $\begin{array}{c}\text { Age in } \\
\text { Years }\end{array}$ & \multicolumn{2}{|c|}{ Group A (N = 50) } & \multicolumn{2}{c|}{ Group B (N = 50) } \\
\hline & $\begin{array}{c}\text { No. of } \\
\text { Patients }\end{array}$ & $\begin{array}{c}\text { Percent } \\
(\%)\end{array}$ & $\begin{array}{c}\text { No. of } \\
\text { Patients }\end{array}$ & $\begin{array}{c}\text { Percent } \\
(\%)\end{array}$ \\
\hline $18-30$ & 16 & 32 & 18 & 36 \\
\hline $30-40$ & 14 & 28 & 24 & 48 \\
\hline $40-50$ & 13 & 26 & 7 & 14 \\
\hline $50-60$ & 5 & 10 & 3 & 6 \\
\hline \multicolumn{3}{|c|}{ Mean $\pm 36.5 \pm 10.934 .12 \pm 9.0$ P value $=0.2396$} \\
Table 3. Comparison of Age Distribution between Two \\
Groups \\
\hline
\end{tabular}

\begin{tabular}{|c|c|c|c|c|}
\hline Name of Surgery & $\begin{array}{c}\text { Group } \\
\text { A }\end{array}$ & $\begin{array}{c}\text { Percent } \\
\text { (\%) }\end{array}$ & $\begin{array}{c}\text { Group } \\
\text { B }\end{array}$ & $\begin{array}{c}\text { Percent } \\
\text { (\%) }\end{array}$ \\
\hline TAH & 15 & 30 & 18 & 51 \\
\hline VH & 20 & 40 & 21 & 41 \\
\hline $\begin{array}{c}\text { Laparotomy } \\
\text { + Myomectomy }\end{array}$ & 8 & 16 & 4 & 12 \\
\hline $\begin{array}{c}\text { Laparotomy+ } \\
\text { Cystectomy }\end{array}$ & 5 & 10 & 3 & 08 \\
\hline Obstructed Hernia & 2 & 4 & 4 & 06 \\
\hline \multicolumn{5}{|c|}{ Table 4. Distribution of Patients in } \\
\hline \multicolumn{4}{|c|}{ Two Groups based on Operative Procedure } \\
\hline
\end{tabular}

\begin{tabular}{|c|c|c|c|c|}
\hline $\begin{array}{c}\text { Side } \\
\text { Effects }\end{array}$ & \multicolumn{2}{|c|}{ Group A } & \multicolumn{2}{c|}{ Group B } \\
\hline & $\begin{array}{c}\text { No. of } \\
\text { Patients }\end{array}$ & $\mathbf{( \% )}$ & $\begin{array}{c}\text { No. of } \\
\text { Patients }\end{array}$ & (\%) \\
\hline Pruritus & 0 & 0 & 5 & 10 \\
\hline Nausea & 3 & 6 & 5 & 10 \\
\hline Vomiting & 9 & 18 & 14 & 28 \\
\hline Hypotension & 0 & 0 & 2 & 4 \\
\hline Table 5. Comparison of Side Effects between Two Groups \\
\hline
\end{tabular}
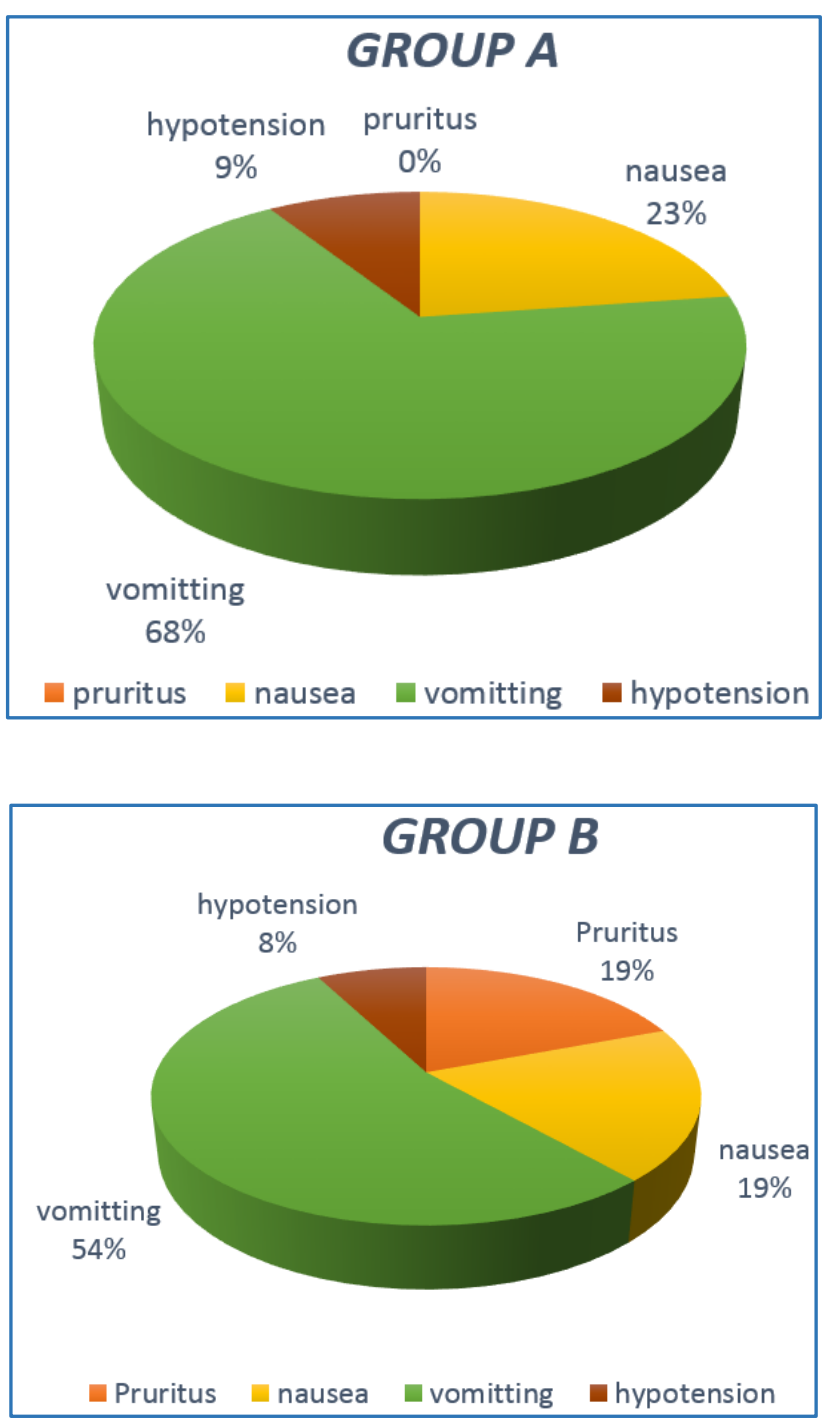

Figure 2. Showing Distribution of Side Effects between Two Groups

\begin{tabular}{|c|c|c|}
\hline \multicolumn{3}{|c|}{ Group A (Onset of Analgesia) } \\
\hline Time in Minutes & No. of Cases & Percent of Cases (\%) \\
\hline 5 & 6 & 12 \\
\hline 6 & 6 & 12 \\
\hline 8 & 6 & 12 \\
\hline 10 & 18 & 36 \\
\hline 12 & 9 & 18 \\
\hline 13 & 1 & 2 \\
\hline 15 & 4 & 8 \\
\hline \multicolumn{2}{|c|}{ Table 6. Time of Onset of Analgesia in Group A } \\
\hline
\end{tabular}




\begin{tabular}{|c|c|c|}
\hline \multicolumn{3}{|c|}{ Group B (Onset of Analgesia) } \\
\hline Time in Minutes & No. of Cases & Percent of Cases (\%) \\
\hline 8 & 3 & 6 \\
\hline 10 & 22 & 44 \\
\hline 14 & 2 & 4 \\
\hline 15 & 5 & 10 \\
\hline 18 & 11 & 21 \\
\hline 20 & 6 & 12 \\
\hline 25 & 1 & 2 \\
\hline \multicolumn{3}{|c|}{ Table 7. Time of Onset of Analgesia in Group B } \\
\hline
\end{tabular}

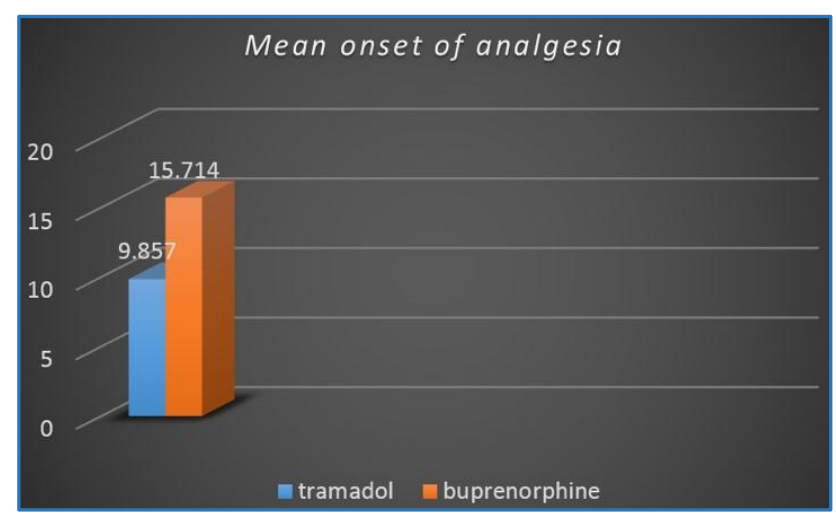

Figure 3. Showing Mean onset of Analgesia between Two Groups

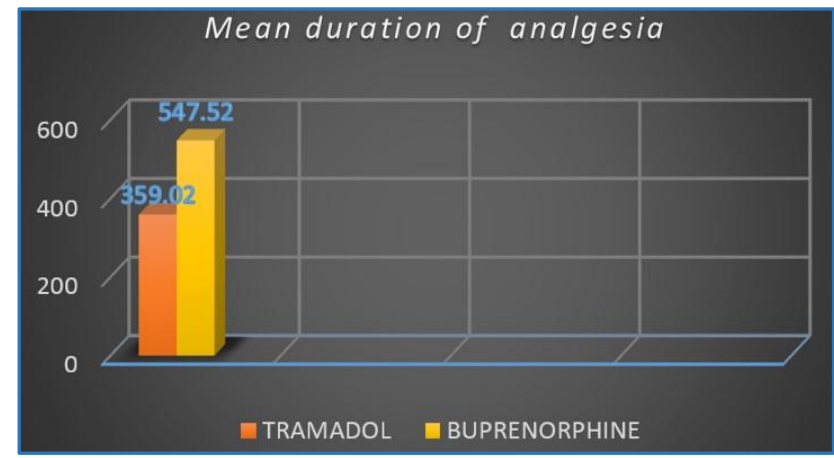

Figure 4. Showing Mean Duration of Analgesia between Two Groups

\begin{tabular}{|c|c|c|c|c|c|}
\hline Group & N & Mean & $\begin{array}{c}\text { Standard } \\
\text { Deviation }\end{array}$ & $\begin{array}{c}\text { t } \\
\text { value }\end{array}$ & $\begin{array}{c}\text { P } \\
\text { value }\end{array}$ \\
\hline $\begin{array}{c}\text { A } \\
\text { (Tramadol) }\end{array}$ & 50 & 9.857 & 3.716 & 2.236 & 0.0452 \\
\hline $\begin{array}{c}\text { B } \\
\text { (Buprenorphine) }\end{array}$ & 50 & 15.714 & 5.851 & & \\
\hline
\end{tabular}

Table 8. Mean Time of Onset of Analgesia in Minutes

\begin{tabular}{|c|c|c|c|}
\hline $\begin{array}{c}\text { Mean Duration } \\
\text { of Analgesia }\end{array}$ & $\begin{array}{c}\text { No. of } \\
\text { Samples }\end{array}$ & $\begin{array}{c}\text { Mean } \\
\text { (In } \\
\text { minutes) }\end{array}$ & $\begin{array}{c}\text { Standard } \\
\text { Deviation } \\
\text { (SD) }\end{array}$ \\
\hline $\begin{array}{c}\text { Group A } \\
\text { (Tramadol) }\end{array}$ & $\mathrm{N}=50$ & 359.02 & 83.853 \\
\hline $\begin{array}{c}\text { Group B } \\
\text { (Buprenorphine) }\end{array}$ & $\mathrm{N}=50$ & 547.52 & 94.223 \\
\hline \multicolumn{4}{|c|}{ Table 9. Mean Duration of Analgesia in Minutes } \\
\hline
\end{tabular}

\section{DISCUSSION}

In the present study, we have compared the efficacy of epidural tramadol with epidural buprenorphine for postoperative pain relief in patients undergoing lower abdominal surgeries.
Several studies have shown that epidural buprenorphine is the most effective drug for post-operative pain relief, at the same time many other studies have also shown that epidural tramadol can give sufficient duration of analgesia with minimal side effects. Also Inj. Tramadol is easily available and free from narcotic abuse related restriction. ${ }^{3}$

In our study, 100 patients posted for elective surgeries were randomly allocated into two groups of 50 patients each. Inclusion criteria of the patients comprised of ASA I, II, age group between 18 - 60 years, both sexes included and were not standardised. The same volume of the drugs was administered in patients of both the groups, Group A received Inj. Tramadol hydrochloride $50 \mathrm{mg}$ diluted in normal saline to a total $12 \mathrm{~mL}$ volume while Group B received Inj. Buprenorphine hydrochloride 100 micrograms diluted in normal saline to a total $12 \mathrm{~mL}$ volume via epidural catheter in post-operative period based on pain intensity assessed by VAS (Visual Analogue Pain Score).

All the patients were followed up in the postoperative period at $0,15,30$ minutes and 1, 2, 3, 6, 8, 10, 12, 24 hours respectively. Parameters like systolic blood pressure, diastolic blood pressure, mean arterial pressure, respiratory rate, heart rate, $\mathrm{SpO} 2$ were recorded.

Rathie $P$ et al (1998) studied the effectiveness and duration of post-operative analgesia with epidural tramadol and they found that epidural tramadol has rapid onset of action and adequate analgesia. ${ }^{4}$

In our study, mean onset of analgesia with epidural tramadol was $9.85 \pm 2.866$ minutes, whereas with epidural buprenorphine it was $15.71 \pm 5.85$ minutes. We found that epidural tramadol has rapid onset of analgesia when compared to epidural Buprenorphine.

Siddik-Sayyid et al (1999) studied the analgesic effect of epidural tramadol in patients who underwent elective caesarean section. They concluded that epidural tramadol provided post-operative analgesia for a period of $4.5 \pm 3.1$ hours. ${ }^{5}$

Rathie P et al (1998) studied 50 patients for effectiveness and duration of post-operative pain relief by epidural tramadol. The mean duration of post-operative analgesia with tramadol 100 mg was $10.26 \pm 2.73$ hours. 4

Delikan et al studied the analgesic effects of epidural tramadol and concluded that $100 \mathrm{mg}$ of tramadol provided post-operative analgesia for 9.46 hours. $^{6}$

Koshy $\mathrm{T}$ et al in 1994 compared epidural morphine and epidural buprenorphine for post-operative pain relief. They found longer duration of analgesia was with epidural Buprenorphine i.e., $19.9 \pm 8$ hours. $^{7}$

Kumar D et al (1997) studied the effectiveness of epidural Buprenorphine and ketamine. The mean post-operative analgesia obtained with epidural Buprenorphine was 13.1 hours. 8

Agarwal M et al in 1998 compared epidural morphine and epidural buprenorphine for post-operative pain relief. They found that mean duration of analgesia was longer with buprenorphine (31.24 hours). ${ }^{9}$

In our study, the mean duration of post-operative analgesia obtained with epidural tramadol was $359.02 \pm$ 83.853 minutes ( 4.5 - 7.3 hours) and with Buprenorphine was $547.52 \pm 94.223$ minutes. (7.5-10.6 hours). Our mean duration of analgesia is correlating with the results of studies conducted by Siddik et al, Rathi P et al, Delikan et al, Kumar D et al, Koshy 
$\mathrm{T}$ et al and Agarwal $\mathrm{M}$ et al. The longer duration of action of Buprenorphine can be well explained based on high lipid solubility and high affinity for opiate receptors.

Delikan AE et al in 1993 studied the efficacy of epidural tramadol in patients undergoing abdominal surgery and found longer duration of post-operative pain relief and high incidence of nausea. 6

Rathie P etal in 1998 studied effectiveness and duration of post-operative pain relief by epidural tramadol and found that nausea and vomiting were common side effects. ${ }^{4}$

In the present study, the incidence of nausea and vomiting were almost similar with both epidural tramadol and epidural buprenorphine. In tramadol group, 3 out of 50 and 9 out of 50 i.e. $6 \%$ and $18 \%$ cases complained of nausea and vomiting. In Buprenorphine group, 5 out of 50 and 14 out of 50 i.e. $10 \%$ and $28 \%$ cases complained of nausea and vomiting.

Koshi $\mathrm{T}$ et al in 1994 compared epidural morphine with epidural buprenorphine for postoperative analgesia and side effects. In their study, hypotension occurred in 1 case in buprenorphine group. ${ }^{7}$

Churubasik S et al in 1996 studied the pain relief with peridural administration of opioids. They felt that epidural tramadol may be useful in clinical routine, because it has cardiovascular stability and has a low potential for central depressive effects, extremely useful where supervision of the patient is not guaranteed.10

In our study, haemodynamics was stable with epidural tramadol when compared to epidural buprenorphine. No incidence of hypotension was found with epidural tramadol.

In buprenorphine group hypotension, however, occurred in 2 cases, which responded well to intravenous fluid administration. This hypotension occurred due to hypovolaemia because of vomiting.

Vickers MD et al in 1992 compared the effect of tramadol on respiration with morphine. They concluded that equianalgesic dose of tramadol has much less effect on respiratory centre compared to morphine.11

Baraka a et al in 1993 compared epidural tramadol and morphine for post-operative analgesia in patients undergoing major abdominal surgeries. They concluded that there is no clinically relevant respiratory depression with epidural tramadol.12

Koshi T et al in 1994 compared epidural morphine with epidural buprenorphine for postoperative analgesia and side effects. The incidence of respiratory depression was zero with epidural buprenorphine. ${ }^{7}$

Y et al in 2005 compared epidural tramadol with epidural morphine for post-operative analgesia in children undergoing urological surgery. They concluded that incidence of respiratory depression was more in the morphine group than in tramadol group. $\mathbf{1 3}$

In the present study, no respiratory depression was found either with epidural tramadol or epidural buprenorphine. Our study results are correlating with Vickers MD, Baraka A, Koshi $\mathrm{T}$ et al studies.

Koshi $\mathrm{T}$ et al in 1994 compared epidural morphine with epidural Buprenorphine for postoperative analgesia and side effects. They found side effects like pruritus occurred in 1 $(3.3 \%)$ case and urinary retention occurred in 8 (26.7\%) cases. ${ }^{7}$
In our study, pruritus occurred in 5 out of 50 i.e. $10 \%$ cases and with epidural buprenorphine. These complications were not observed with epidural tramadol.

\section{CONCLUSION}

The advantage of epidurally administered opiates would seem to be its high quality of analgesia at low dosage. The results of our study confirmed our expectations that buprenorphine provides excellent analgesia given epidurally in incremental low dosage. Its quality of analgesia is better, duration of action is better and duration of action longer than tramadol. Buprenorphine has thirty times more potency than morphine in controlling post-operative pain. Therefore, we conclude that epidural buprenorphine provides adequate and prolonged post-operative analgesia. The only noticeable side effect being nausea and vomiting which can be obtunded by use of an antiemetic agent.

\section{REFERENCES}

[1] Stoelting RK. Pharmacology and physiology in anaesthesia practice. $3^{\text {rd }}$ edn. Philadelphia: LippincottRaven 1999:77-112.

[2] Gut-Stein HB, Akil H. Opioid analgesics. In: Hardman JG, Limbird LE, Gilman AG. eds. Goodman and Gilman's the pharmacological basia of therapeutics. 10 th edn. New York: McGraw-Hill 2001:337-619.

[3] Miller RD. Anaesthisia. $6^{\text {th }}$ edn. Philadelphia: Churchill Livingstone 2005:379-425.

[4] Rathi P, Verma RS, Jatav TS, et al. Post-operative pain relief by epidural tramadol. Indian $\mathrm{J}$ Anesthesia 1998;42:26-31.

[5] Siddik-Sayyid S, Aouad-Maroun M, Sleiman D, et al. Epidural treatment for postoperative pain after Caesarean section. Canadian Journal of Anaesthesia 1999;46(8):731-5.

[6] Delikan AE, Vijayan R. Epidural tramadol for postoperative pain relief. Anaesthesia 1993;48(4):328-31.

[7] Koshi T, Afzal l, Kaur B. A comparison epidural morphine and epidural buprenorphine for postoperative analgesia. Ind J Anaesth 1994;42:305.

[8] Kumar D, Gupta D. Comparative study of epidural Buprenorphine and Ketamine for postoperative pain relief. IJA 1997;41:38-49.

[9] Agarwal M, Rattan A, Bhattacharya P, et al. Evaluation of post-operative analgesia efficacy of extradural buprenorphine. Ind J Anesthesia 1997;42:49-54.

[10] Chrubasik S, Chrubasik J. Treatment of postoperative pain with peridural administration of opioids. Anesthesiology Reanim 1995;20(1):16-25.

[11] Vickers MD, O'Flaherty D, Szekely SM, et al. Tramadol: pain relief by an opioid without respiratory depression. Anesthesia Journal 1992;47(4):291-6.

[12] Baraka A, Jabbour S, Ghabash M, et al. A Comparison of epidural tramadol and epidural morphine for postoperative analgesia. Canadian J Anesthesia 1993;40(4):308-13.

[13] Yaddanapudi LN, Wig J, Singh B, et al. Comparison of efficacy and side effects of epidural tramadol and morphine in patients undergoing laminectomy. A repeated dose study. Neurol India 2000;48(4):398400. 